\title{
Boginia virus, a newfound hantavirus harbored by the Eurasian water shrew (Neomys fodiens) in Poland
}

\author{
Se Hun Gu${ }^{1}$, Janusz Markowski ${ }^{2}$, Hae Ji Kang ${ }^{1}$, Janusz Hejduk², Beata Sikorska ${ }^{3}$, Paweł P Liberski ${ }^{3}$ \\ and Richard Yanagihara ${ }^{*}$
}

\begin{abstract}
Background: Guided by decades-old reports of hantaviral antigens in the Eurasian common shrew (Sorex araneus) and the Eurasian water shrew (Neomys fodiens) in European Russia, we employed RT-PCR to analyze lung tissues of soricine shrews, captured in Boginia, Huta Dłutowska and Kurowice in central Poland during September 2010, 2011 and 2012.

Findings: In addition to Seewis virus (SWSV), which had been previously found in Eurasian common shrews elsewhere in Europe, a genetically distinct hantavirus, designated Boginia virus (BOGV), was detected in Eurasian water shrews captured in each of the three villages. Phylogenetic analysis, using maximum likelihood and Bayesian methods, showed that BOGV formed a separate lineage distantly related to SWSV.

Conclusions: Although the pathogenic potential of BOGV and other recently identified shrew-borne hantaviruses is still unknown, clinicians should be vigilant for unusual febrile diseases and clinical syndromes occurring among individuals reporting exposures to shrews.
\end{abstract}

Keywords: Hantavirus, Neomys, Sorex, Shrew, Phylogeny, Poland

\section{Findings}

Although hantaviral antigens were detected by the indirect immunofluorescent antibody test and enzyme immunoassay in tissues of the Eurasian common shrew (Sorex araneus), Eurasian pygmy shrew (Sorex minutus) and Eurasian water shrew (Neomys fodiens) in European Russia and the former Yugoslavia more than two decades ago [1-3], shrews (order Soricomorpha) had been dismissed as being unimportant in the ecology and evolution of hantaviruses. Guided by these longignored reports, and aided by access to archival tissue collections, an opportunistic search, employing reverse transcription-polymerase chain reaction (RT-PCR), demonstrated a genetically distinct hantavirus, named Seewis virus (SWSV), in a Eurasian common shrew captured in Graubünden, Switzerland [4].

\footnotetext{
* Correspondence: ryanagih@hawaii.edu

${ }^{1}$ Pacific Center for Emerging Infectious Diseases Research, John A. Burns School of Medicine, University of Hawaii at Manoa, 651 Ilalo Street, BSB320L, Honolulu, Hawaii 96813, USA

Full list of author information is available at the end of the article
}

Subsequent studies have indicated that SWSV is widespread across the vast distribution of its soricid reservoir, in Austria, Czech Republic, Slovakia, Finland, Germany, Hungary and Russia [5-7]. SWSV has also been detected in the Siberian large-toothed shrew (Sorex daphaenodon) and tundra shrew (Sorex tundrensis) in Siberia [6]. And in a comprehensive study on the phylogeography of SWSV in central Europe, SWSV was shown to exhibit distinct geographicspecific clustering in Eurasian common shrews and Eurasian pygmy shrews [7]. The overlapping geographic ranges of the Eurasian common shrew and other shrew species in central Poland provided an opportunity to investigate the existence of SWSV and other soricine shrew-borne hantaviruses.

Shrews were captured, using live traps and pitfall traps, placed $5 \mathrm{~m}$ apart and baited with raw bacon or beef, during the month of September in 2010, 2011 and/or 2012 in Boginia (51 $20^{\prime} 26.80 \mathrm{~N}, 1^{\circ} 36^{\prime} 41.36 \mathrm{E}$ ), Huta Dłutowska $\left(51^{\circ} 35^{\prime} 49.51 \mathrm{~N}, 19^{\circ} 22^{\prime} 46.80 \mathrm{E}\right)$ and/or

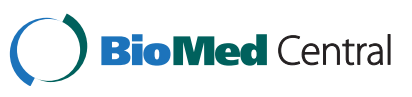

(c) 2013 Gu et al.; licensee BioMed Central Ltd. This is an Open Access article distributed under the terms of the Creative Commons Attribution License (http://creativecommons.org/licenses/by/2.0), which permits unrestricted use, distribution, and reproduction in any medium, provided the original work is properly cited. 


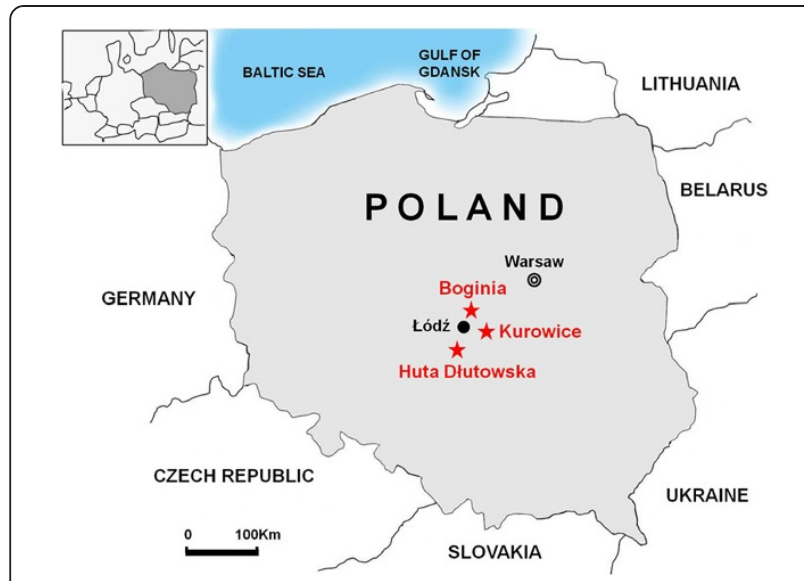

Figure 1 Map of Poland, showing the three villages of Boginia, Huta Dłutowska and Kurowice, in close proximity to tódź, where hantavirus-infected soricine shrews were captured.

Kurowice (51 $39^{\prime} 48.03$ N, 1942' 20.92 E), three closely located villages within Łódź East County, in central Poland (Figure 1). All trapping and experimental procedures on shrews were approved by the General Directorate for Environmental Protection (DOP-OZGiZ. 4200/N2732/10/JRO, DOP-OZGiZ.6401.05.25.2011kp.3 and DOP-OZGiZ.6401.05.28.2011kp.1).

Total RNA, extracted from lung tissues preserved in RNAlater $^{\ominus}$ RNA Stabilization Reagent (Qiagen) from 40 shrews (Table 1), was analyzed for hantavirus RNA by RT-PCR, using oligonucleotide primers designed from soricomorph-borne hantaviruses [5,8-10]. Using Clustal W [11], pair-wise alignment and comparison of the 795- and 782-nucleotide regions of the $M$ and $\mathrm{L}$ segments, respectively, revealed a genetically distinct hantavirus, named Boginia virus (BOGV), in 3 of 6 Eurasian water shrews captured in Boginia, Huta Dłutowska and Kurowice (Tables 1 and 2). The high prevalence of BOGV infection in Eurasian water shrews captured in three separate villages in central Poland suggested a well-established reservoir hosthantavirus relationship.

The L-segment genetic variation between BOGV strains 2073,2074 and 2177 was $3.1-15.0 \%$ at the nucleotide level, but there was $100 \%$ amino acid homology. The observation that hantaviruses exhibit high sequence conservation at the amino acid level, despite considerable divergence of more than $15 \%$ at the nucleotide level, has been made previously $[5-7,12]$. This has been attributed to the longstanding co-adaptation between virus and reservoir host, as well as the strong selection pressure to preserve function of the three gene products.

BOGV and other representative soricine shrew-borne hantaviruses exhibited M- and L-segment sequence similarity of only $71.7-76.7 \%$ and $75.1-87.7 \%$ at the nucleotide and amino acid levels, respectively. The taxonomic identities of the BOGV-infected Eurasian water shrews were verified by mitochondrial DNA sequence analysis (GenBank accession no. KC537796 for BOGV 2073; KC537797 for BOGV 2074; and KC537798 for BOGV 2177).

Eurasian common shrews, captured in Boginia and Huta Dłutowska, as well as a Eurasian pygmy shrew from Kurowice, were infected with SWSV (Table 1), indicating simultaneous circulation of genetically distinct hantaviruses in syntopic shrew species captured in the same trap sites. Recently, SWSV was detected in Eurasian pygmy shrews in Germany and the Czech Republic [7], but the low prevalence is suggestive of spillover. Nevertheless, carriage of the same hantavirus in two soricine shrew species in central Poland parallels findings of host sharing of SWSV in other Sorex shrew species [6,7], as well as of rodent-borne hantaviruses, such as Tula virus, in several arvicolid rodent species [12-14].

Phylogenetic trees, generated by maximum likelihood and Bayesian methods, implemented in PAUP* (Phylogenetic Analysis Using Parsimony, 4.0b10) [15],

Table 1 RT-PCR detection of hantavirus RNA in tissues of soricine shrews from Poland

\begin{tabular}{|c|c|c|c|c|}
\hline Genus species & Capture site & Capture dates & Number tested & Number positive \\
\hline \multirow[t]{3}{*}{ Sorex araneus } & Boginia & September 20-22, 2010 & 3 & 1 \\
\hline & & September 20-22, 2011 & 6 & 0 \\
\hline & Huta Dłutowska & September 15-18, 2011 & 9 & 2 \\
\hline \multirow[t]{3}{*}{ Sorex minutus } & Boginia & September 21-22, 2011 & 2 & 0 \\
\hline & Huta Dłutowska & September 16-18, 2011 & 4 & 0 \\
\hline & Kurowice & September 7-14, 2012 & 10 & 1 \\
\hline \multirow[t]{3}{*}{ Neomys fodiens } & Boginia & September 22, 2011 & 1 & 1 \\
\hline & Huta Dłutowska & September 22, 2011 & 1 & 1 \\
\hline & Kurowice & September 9-14, 2012 & 4 & 1 \\
\hline
\end{tabular}


Table 2 Partial S-, M- and/or L-segment sequences of hantaviruses detected in lung tissues of soricine shrews captured in central Poland

\begin{tabular}{|c|c|c|c|c|c|}
\hline \multirow[b]{2}{*}{ Virus strain } & \multirow[b]{2}{*}{ Capture site } & \multirow[b]{2}{*}{ Capture date } & \multicolumn{3}{|c|}{ Nucleotides and GenBank accession numbers } \\
\hline & & & S segment & M segment & L segment \\
\hline SWSV 1107 & Boginia & 22-Sep-2010 & 690 nt (435-1025) JX990921 & 647 nt (1520-2100) JX990967 & 806 nt (2520-3400) JX990936 \\
\hline SWSV 2048 & Huta Dłutowska & 16-Sep-2011 & & & 756 nt (2541-3296) JX990944 \\
\hline SWSV 2049 & Huta Dłutowska & 17-Sep-2011 & & & 357 nt (2900-3300) JX990945 \\
\hline SWSV 2121 & Kurowice & 12-Sep-2012 & & & 316 nt (2998-3313) KC537794 \\
\hline BOGV 2073 & Huta Dłutowska & 22-Sep-2011 & & & 394 nt (2520-2935) JX990964 \\
\hline BOGV 2074 & Boginia & 22-Sep-2011 & & 795 nt (1520-2355) JX990966 & 783 nt (2541-3323) JX990965 \\
\hline BOGV 2177 & Kurowice & 9-Sep-2012 & & & 408 nt (2520-2935) KC537795 \\
\hline
\end{tabular}

Abbreviations: BOGV, Boginia virus; SWSV, Seewis virus; nt, nucleotides.

RAxML Blackbox webserver [16] and MrBayes 3.1 [17], under the best-fit GTR $+\mathrm{I}+\Gamma$ model of evolution established using jModeltest 0.1.1 [18], showed that BOGV formed a separate lineage distantly related to SWSV (Figure 2), in keeping with the evolutionary relationship of their soricid hosts. As expected, phylogenetic trees showed SWSV to segregate generally along geographic-specific lineages (Figure 2), as reported previously [5-7].

As for several other shrew-borne hantaviruses, the sequence divergence of BOGV presented insurmountable difficulties in obtaining the full genome sequence. Sequencing efforts were also severely constrained by the limited availability of tissues, and poor-quality tissue RNA thwarted efforts at employing next generation sequencing technology. Efforts, now underway, to rapidly freeze tissues collected from Eurasian water shrews captured in central Poland will be used for virus isolation attempts.

The detection of a novel, genetically distinct hantavirus in the Eurasian water shrew captured in central Poland confirms decades-old reports that this shrew species might serve as a reservoir [2]. Whether other Neomys species, such as the Mediterranean water shrew (Neomys anomalus), also harbor a BOGV-like hantavirus, rather than SWSV, is unknown. Nevertheless, neither physical proximity with sharing of habitats nor genetic relatedness of shrew host species allows accurate prediction of the hantavirus species in a particular reservoir. That said, this study provides clear evidence of the co-existence of two genetically distinct hantaviruses in their soricomorph reservoir host species inhabiting the same ecological niche. To what extent hantavirus spillover occurs between reservoir shrews and rodents is currently under investigation.

Unlike most soricine shrew species, the Eurasian water shrew is comparatively large, measuring approximately
$10 \mathrm{~cm}$ in body length, with a long tail. It is highly territorial and lives a solitary life near freshwater and other wetland habitats, including rivers, streams, marshes, bogs and damp grasslands and meadows, at sea level to elevations over 2,500 m [19,20]. Eurasian water shrews forage almost exclusively underwater, using to great effect their venomous saliva to feast on aquatic invertebrates, including insects, gastropods and crustaceans, as well as occasionally small vertebrates, such as amphibians and fish. Some terrestrial insects, such as dipteran larvae, are also consumed. The vast distribution of the Eurasian water shrew $[19,20]$, spanning from the United Kingdom and Scandinavia throughout Europe and much of Asia, including far eastern Russia and Sakhalin, where other syntopic soricomorphs and rodents reside, provides rich opportunities to investigate the genetic diversity and phylogeography of BOGV.

That distinct diseases or clinical syndromes have yet to be attributed to shrew-borne hantaviruses is not particularly surprising, given that most hantaviruses are nonpathogenic. Neotomine and sigmodontine rodents were known to harbor hantaviruses long before the terrifying outbreak of a rapidly progressive, frequently fatal disease (now known as hantavirus cardiopulmonary syndrome) signaled the highly pathogenic nature of these hantaviruses [21-23]. Similarly, while the pathogenic potential of BOGV and other recently identified, still-orphan soricid-borne hantaviruses is still unknown, active vigilance by physicians and public health workers for unusual febrile syndromes, occurring among individuals reporting either contact with shrews or exposure to wetlands that may be contaminated by the Eurasian water shrew, would be crucial to uncover an etiological association. Intensive investigations are underway to isolate and further characterize BOGV to ascertain its impact on human health. 


\section{Competing interests}

The authors declare that they have no competing interests.

\section{Authors' contributions}

SHG and HJK performed primer design, RNA extraction, RT-PCR and DNA sequencing reactions and phylogenetic analysis. JM and JH conducted trapping expeditions and collected shrew tissues. BS and PPL provided logistical support. RY conceived the project and provided overall scientific oversight. All authors contributed to the preparation of the final manuscript. All authors read and approved the final manuscript.

\section{Acknowledgements}

This work was supported in part by U.S. Public Health Service grants R01Al075057 from the National Institute of Allergy and Infectious Diseases and P20GM103516 from the National Institute of General Medical Sciences, National Institutes of Health, and by grant N N303 604538 from the State Committee for Scientific Research, Ministry of Scientific Research and Technology Information in Poland.

\section{Author details}

${ }^{1}$ Pacific Center for Emerging Infectious Diseases Research, John A. Burns School of Medicine, University of Hawaii at Manoa, 651 Ilalo Street, BSB320L, Honolulu, Hawaii 96813, USA. ²Department of Teacher Training and Biodiversity Studies, Faculty of Biology and Environmental Protection, University of Łódź, Łódź, Poland. ${ }^{3}$ Department of Molecular Pathology and Neuropathology, Medical University of Łódź, Łódź, Poland.

\section{Received: 3 March 2013 Accepted: 10 May 2013}

Published: 22 May 2013

\section{References}

1. Gavrilovskaya IN, Apekina NS, Myasnikov YA, Bernshtein AD, Ryltseva EV, Gorbachkova EA, Chumakov MP: Features of circulation of hemorrhagic fever with renal syndrome (HFRS) virus among small mammals in the European U.S.S.R. Arch Virol 1983, 75:313-316.

2. Tkachenko EA, Ivanov AP, Donets MA, Miasnikov YA, Ryltseva EV, Gaponova LK, Bashkirtsev VN, Okulova NM, Drozdov SG, Slonova RA, Somov GP, Astakhova TI: Potential reservoir and vectors of haemorrhagic fever with renal syndrome (HFRS) in the U.S.S.R. Ann Soc Belg Med Trop 1983, 63:267-269

3. Gligic A, Stojanovic R, Obradovic M, Hlaca D, Dimkovic N, Diglisic G, Lukac V, Ler Z, Bogdanovic R, Antonijevic B, Ropac D, Avsic T, LeDuc JW, Ksiazek T, Yanagihara R, Gajdusek DC: Hemorrhagic fever with renal syndrome in Yugoslavia: epidemiologic and epizootiologic features of a nationwide outbreak in 1989. Eur J Epidemiol 1992, 8:816-825.

4. Song J-W, Gu SH, Bennett SN, Arai S, Puorger M, Hilbe M, Yanagihara R: Seewis virus, a genetically distinct hantavirus in the Eurasian common shrew (Sorex araneus). Virol J 2007, 4:114

5. Kang HJ, Arai S, Hope AG, Song J-W, Cook JA, Yanagihara R: Genetic diversity and phylogeography of Seewis virus in the Eurasian common shrew in Finland and Hungary. Virol J 2009, 6:208.

6. Yashina LN, Abramov SA, Gutorov W, Dupal TA, Krivopalov AV, Panov W, Danchinova G, Vinogradov V, Luchnikova E, Hay J, Kang HJ, Yanagihara R: Seewis virus: phylogeography of a shrew-borne hantavirus in Siberia, Russia. Vector Borne Zoonotic Dis 2010, 10:585-591.

7. Schlegel M, Radosa L, Rosenfeld UM, Schmidt S, Triebenbacher C, Löhr PW Fuchs $D$, Heroldová $M$, Jánová E, Stanko M, Mošanský L, Fričová J, Pejčoch M, Suchomel J, Purchart L, Groschup MH, Krüger DH, Klempa B, Ulrich RG: Broad geographical distribution and high genetic diversity of shrewborne Seewis hantavirus in Central Europe. Virus Genes 2012, 45:48-55.

8. Song J-W, Kang HJ, Song KJ, Truong TT, Bennett SN, Arai S, Truong NU, Yanagihara R: Newfound hantavirus in Chinese mole shrew, Vietnam. Emerg Infect Dis 2007, 13:1784-1787.

9. Arai S, Ohdachi SD, Asakawa M, Kang HJ, Mocz G, Arikawa J, Okabe N, Yanagihara R: Molecular phylogeny of a newfound hantavirus in the Japanese shrew mole (Urotrichus talpoides). Proc Natl Acad Sci USA 2008, 105:16296-16301.

10. Kang HJ, Bennett SN, Sumibcay L, Arai S, Hope AG, Mocz G, Song J-W Cook JA, Yanagihara R: Evolutionary insights from a genetically divergent hantavirus harbored by the European common mole (Talpa europaea). PLoS One 2009, 4:e6149.
11. Thompson JD, Higgins DG, Gibson TJ: CLUSTAL W: improving the sensitivity of progressive multiple sequence alignment through sequence weighting, position-specific gap penalties and weight matrix choice. Nucleic Acids Res 1994, 22:4673-4680.

12. Schlegel M, Kindler E, Essbauer SS, Wolf R, Thiel J, Groschup MH, Heckel G, Oehme RM, Ulrich RG: Tula virus infections in the Eurasian water vole in Central Europe. Vector Borne Zoonotic Dis 2012, 12:503-513.

13. Schmidt-Chanasit J, Essbauer S, Petraityte R, Yoshimatsu K, Tackmann K, Conraths FJ, Sasnauskas K, Arikawa J, Thomas A, Pfeffer M, Schaminghausen JJ, Spiettstoesser W, Wenk M, Heckel G, Ulrich RG: Extensive host sharing of central European Tula virus. J Virol 2010, 84:459-474.

14. Song J-W, Gligic A, Yanagihara R: Identification of Tula hantavirus in Pitymys subterraneus captured in the Cacak region of Serbia-Yugoslavia. Int J Infect Dis 2002, 6:31-36.

15. Swofford D: PAUP*: Phylogenetic Analysis Using Parsimony ( ${ }^{*}$ and Other Methods). Sunderland, Massachusetts: Sinauer Associates; 2003.

16. Stamatakis $A$, Hoover $P$, Rougemont J: A rapid bootstrap algorithm for the RAxML web servers. Syst Biol 2008, 57:758-771.

17. Ronquist F, Huelsenbeck JP: MrBayes 3: Bayesian phylogenetic inference under mixed models. Bioinformatics 2003, 19:1572-1574.

18. Posada D: jModelTest: phylogenetic model averaging. Mol Biol Evol 2008 , 25:1253-1256.

19. Nowak RM: Walker's Mammals of the World. 5th edition. Baltimore, Maryland: Johns Hopkins University Press; 1999.

20. Spitzenberger F: Neomys fodiens. In The Atlas of European Mammals. T\& AD Poyser for the Societas Europaea Mammalogica. Edited by Mitchell-Jones AJ, Amori G, Bogdanowicz W, Krystufek B, Reijnders PHJ, Spitzenberger F, Stubbe M, Thissen JBM, Vohralík V, Zima J. London: Academic Press; 1999:61-62.

21. Yanagihara R, Daum CA, Lee P-W, Baek LJ, Amyx HL, Gajdusek DC, Gibbs CJ $\mathrm{Jr}$ : Serological survey of prospect hill virus infection in indigenous wild rodents in the USA. Trans R Soc Trop Med Hyg 1987, 81:42-45.

22. Nichol ST, Spiropoulou CF, Morzunov S, Rollin PE, Ksiazek TG, Feldmann H, Sanchez A, Childs J, Zaki S, Peters CJ: Genetic identification of a hantavirus associated with an outbreak of acute respiratory illness. Science 1993, 262:914-917.

23. Nerurkar VR, Song J-W, Song K-J, Nagle JW, Hjelle B, Jenison S, Yanagihara R: Genetic evidence for a hantavirus enzootic in deer mice (Peromyscus maniculatus) captured a decade before the recognition of hantavirus pulmonary syndrome. Virology 1994, 204:563-568.

\section{doi:10.1186/1743-422X-10-160}

Cite this article as: Gu et al.: Boginia virus, a newfound hantavirus harbored by the Eurasian water shrew (Neomys fodiens) in Poland. Virology Journal 2013 10:160.

\section{Submit your next manuscript to BioMed Central and take full advantage of:}

- Convenient online submission

- Thorough peer review

- No space constraints or color figure charges

- Immediate publication on acceptance

- Inclusion in PubMed, CAS, Scopus and Google Scholar

- Research which is freely available for redistribution 